\title{
A Historical Overview of Market Abuse Prohibition in the United Kingdom
}

\section{Howard Chitimira}

\author{
LLB LLM LLD \\ Lecturer, Faculty of Law, North-West University \\ Email:Howard.Chitimira@nwu.ac.za/Email:tafarachitimira@gmail.com
}

\section{Doi:10.5901/mjss.2014.v5n20p49}

\begin{abstract}
It is important to note that the United Kingdom's market abuse regime has a separate and specific statute that deals with insider trading and another statute which broadly deals with market manipulation and other related market abuse activities. The market abuse legislation in the United Kingdom has further been carefully formulated to incorporate some of the provisions of the 2003 European Directive on market abuse. Consequently, this broad and extensive regulatory approach has led countries in other jurisdictions, including South Africa, to follow some of the enforcement approaches of the United Kingdom's market abuse regime, especially with regard to the prohibition on insider trading. It is against this background that this article will, where applicable, undertake a comparative analysis of the market abuse prohibition in the United Kingdom and South Africa to explore their similarities and differences. To this end, a general historical overview of the insider trading legislation will be discussed first, followed by a similar discussion on the prohibition of market manipulation practices. Lastly, the available penalties will be discussed and thereafter, possible recommendations and/or concluding remarks will be provided.
\end{abstract}

Keywords: market abuse, insider trading, United Kingdom, penalties, market manipulation.

\section{Introduction}

It is important to note that the United Kingdom (the UK)'s market abuse ${ }^{1}$ regime has a separate and specific statute that deals with insider trading ${ }^{2}$ and another statute which broadly deals with market manipulation and other related market abuse activities. ${ }^{3}$ The market abuse legislation in the UK has further been carefully formulated to incorporate some of the provisions of the 2003 European Directive ${ }^{4}$ on market abuse. ${ }^{5}$ Consequently, this broad and extensive regulatory approach has led countries in other jurisdictions, ${ }^{6}$ including South Africa, ${ }^{7}$ to follow some of the enforcement approaches of the UK's market abuse regime, especially with regard to the prohibition on insider trading. ${ }^{8}$ It is against this background that this article will, where applicable, undertake a comparative analysis of the market abuse prohibition in the UK and South Africa to explore their similarities and differences. To this end, a general historical overview of the insider trading legislation will be discussed first, followed by a similar discussion on the prohibition of market manipulation practices. Lastly, the available penalties will be discussed and thereafter, possible recommendations and/or concluding remarks will be provided.

\footnotetext{
${ }^{1}$ Refers to both insider trading and market manipulation in this article.

2 The Criminal Justice Act 1993 (c 36), hereinafter referred to as the Criminal Justice Act.

${ }^{3}$ See the Financial Services and Markets Act 2000 (c 8), hereinafter referred to as the Financial Services and Markets Act. Also see Avgouleas The Mechanics and Regulation of Market Abuse: A Legal and Economic Analysis (2005) 307.

${ }^{4}$ See the Directive of the European Parliament and Council of 28 January 2003 on insider dealing and market manipulation (market abuse) 2003/6/EC [2003] OJ L96/16 (hereinafter referred to as the EU Market Abuse Directive).

${ }^{5}$ Barnes Stock Market Efficiency, Insider Dealing and Market Abuse (2009) 125.

${ }^{6}$ See Bhattacharya \& Daouk "The World Price of Insider Trading" 2002 Journal of Finance 75 75-108; Lyon \& Du Plessis The Law of Insider Trading in Australia (2005) 159-168 \& Avgouleas The Mechanics and Regulation of Market Abuse 75-502, for further analysis on the regulation and enforcement of the market abuse ban in other countries.

${ }^{7}$ Generally see ss 78; 80; 81 \& 82 of the Financial Markets Act 19 of 2012, hereinafter referred to as the Financial Markets Act. See further Van Deventer "Anti-Market Abuse Legislation in South Africa" (10-06-2008) 1-5 <http://www.fsb.co.za/public/marketabuse/ FSBReport.pdf> (accessed 05-05-2013); Myburgh \& Davis "The Impact of South Africa's Insider Trading Regime: A Report for the Financial Services Board" (25-03-2004) 8-33 <http://www.genesis-analytics.com/public/FSBReport.pdfs (accessed 09-02-2013). Also see Chitimira A Comparative Analysis of the Enforcement of Market Abuse Provisions (2012) 305-353; Botha "Control of Insider Trading in South Africa: A Comparative Analysis" 1991 SA Merc LJ 1 1-18; Botha "Increased Maximum Fine for Insider Trading: A Realistic and Effective Deterrent?" 1990 SALJ 504-508: Chitimira The Regulation of Insider Trading in South Africa: A Roadmap for an Effective, Competitive and Adequate Regulatory Statutory Framework (2008) LLM dissertation, University of Fort Hare, 41-72; Osode "The new South African Insider Trading Act: Sound law reform or legislative overkill?" 2000 Journal of African Law 239 239-263; Jooste "A critique of the insider trading provisions of the 2004 Securities Services Act" 2006 SALJ 437 441-460; Van Deventer "New watchdog for insider trading" 1999 FSB Bulletin 23 \& Luiz "Insider Trading Regulation - If at First You Don't Succeed..." 1999 SA Merc LJ 136 136-151.

${ }^{8}$ Other countries that were also influenced by the United Kingdom's insider trading legislation include Germany, Italy, Canada, Mexico and France. See further Steinberg "Insider Trading Regulation-A Comparative Perspective" 2003 The International Lawyer 153 154-171.
} 


\section{Historical Overview of Insider Trading Prohibition}

The UK's insider trading regime has a relatively short history. ${ }^{9}$ Until 1980 , insider trading was not statutorily prohibited in the UK. ${ }^{10}$ Prior to this, two legislative attempts to outlaw insider trading in the early 1970 s were unsuccessfully made. ${ }^{11}$ This was further worsened by the fact that the common law failed to provide clear opportunities for the prejudiced persons to seek their redress in the civil courts. ${ }^{12}$

Consequently, the legislature enacted the Companies Act 1980. ${ }^{13}$ However, this Act made insider trading a criminal offence only in certain specified circumstances. ${ }^{14}$ Moreover, the Companies Act 1980 provided some requirements for directors, members of their families and substantial shareholders to report any dealings in shares of their companies to discourage the misuse of non-public inside information..$^{15}$

In an attempt to improve the prohibition of insider trading in the UK, the provisions of the Companies Act 1980 were revised and consolidated into the Companies Act 1985. ${ }^{16}$ These provisions banning insider trading were further revised and re-branded as the Company Securities (Insider Dealing) Act 1985. ${ }^{17}$ The Insider Dealing Act prohibited individuals (insiders) ${ }^{18}$ who had access to material non-public inside information by virtue of their position within a company from dealing in the securities of the company while having such information. Furthermore, these insiders were prohibited from making a selective disclosure of non-public inside information to others (tipping) and it also prohibited the tippees from dealing in securities on the basis of such information. ${ }^{19}$ In addition, individuals with non-public information about a suggested takeover of a company were prohibited from dealing in that company's stock. However, the provisions of the Insider Dealing Act applied only to individuals who knowingly dealt in the affected securities while in possession of material non-public inside information. ${ }^{20}$ Furthermore, the provisions of the Insider Dealing Act provided only criminal sanctions for insider trading violations. As a result, the scope and impact of this Act was somewhat restricted and narrow. ${ }^{21}$

Owing to a considerable uncertainty on the effectiveness of the provisions of the Insider Dealing Act, the legislature introduced the Financial Services Act 1986. ${ }^{22}$ The provisions of the Financial Services Act were inter alia aimed at supplementing and strengthening the enforcement of the insider trading ban in the UK. ${ }^{23}$ However, the provisions of this Act were still applicable only to individuals and offered no civil remedy for such individuals who were prejudiced by insider trading.

The provisions of the Insider Dealing Act (as amended by the Financial Services Act) were therefore, superseded by the Criminal Justice Act. ${ }^{24}$ Thus, the provisions of the Criminal Justice Act were, among other things, targeted at removing the loopholes that were contained in its predecessors by incorporating some recommendations from the European Council Directive on insider trading ${ }^{25}$ and extending the application of the prohibition on insider trading to a wider class of securities ${ }^{26}$ and individuals. ${ }^{27}$ Specifically, three classes of individuals (insiders) that are statutorily prohibited from committing insider trading include firstly, a person who has direct knowledge of non-public inside information (primary insider) by virtue of being a director, employee or shareholder of an issuer of securities or by virtue

\footnotetext{
${ }_{9}^{9}$ Avgouleas The Mechanics and Regulation of Market Abuse 308. Notably, in this sub-heading, the principal focus is on the provisions of the insider trading legislation in the UK that deal with the enforcement. Thereafter a comparative analysis with similar developments in South Africa will be carried out.

10 Barnes Stock Market Efficiency, Insider Dealing 125

${ }^{11}$ For instance in 1973, the Conservative government published a Companies Bill that would have prohibited insider trading, but it collapsed when the said government was defeated in the February 1974 general election. A similar Bill was proposed by the Labour government in 1978 and it suffered the same fate when the Labour government lost the May 1979 general election.

12 In other words, the use of inside information without some affirmative obligation to disclose it did not give rise to civil liability for insider trading. See further Rider, Alexander, Linklater \& Bazley Market Abuse and Insider Dealing (2009) 44.

13 (c 22), hereinafter referred to as the Companies Act 1980.

14 Also see ss 68 to 73 of the Companies Act 1980. Also see generally Blair \& Walker Financial Services Law (2006) 267.

15 Notwithstanding the fact that these disclosure and reporting duties were probably useful and justified in many respects, it is debatable whether such duties had the practical effect of prohibiting insider trading and other related illicit trading practices. See further Rider, Alexander, Linklater \& Bazley Market Abuse and Insider Dealing 44.

16 (c 6), hereinafter referred to as the Companies Act 1985.

17 (c 8), hereinafter referred to as the Insider Dealing Act; also see Rider, Alexander, Linklater \& Bazley Market Abuse and Insider Dealing 44.

18 Such insiders included directors, officers, employees and various kinds of agents of the company.

${ }^{19}$ See further Rider, Alexander, Linklater \& Bazley Market Abuse and Insider Dealing 45.

20 Thus, possible insider trading violations by juristic persons were not covered. Generally see $s$ 10(b).

${ }^{21}$ In spite of the fact that the insider trading prohibition was effective since 1980, there were no convictions under the Insider Dealing Act until the late 1980s. See further Rider, Alexander, Linklater \& Bazley Market Abuse and Insider Dealing 45.

22 (c 60), hereinafter referred to as the Financial Services Act.

23 Ss 173 to 178 of the Financial Services Act. Also see further Rider, Alexander, Linklater \& Bazley Market Abuse and Insider Dealing 44.

24 The Criminal Justice Act came into force on 1 March 1994 together with two ancillary statutory instruments namely, the Insider Dealing (Securities and Regulated Markets) Order 1994 \& the Traded Securities (Disclosure) Regulation 1994. See further Rider, Alexander, Linklater \& Bazley Market Abuse and Insider Dealing 45.

25 See Council Directive (89/592)/EEC, Article 1(2). This enabled the UK enforcement authorities to investigate all individuals who engage in insider trading activity in the UK and elsewhere in the European Union (the EU). See further Rider, Alexander, Linklater \& Bazley Market Abuse and Insider Dealing 48.

${ }^{26}$ See the definition of price-affected securities in Schedule 2 of the Criminal Justice Act.

27 S 57 read with ss 52; 55(3)(b) \& 56(2) of the Criminal Justice Act.
} 
of their employment or office. ${ }^{28}$ Secondly, the Criminal Justice Act prohibits an individual (secondary insider) who obtains non-public inside information either directly or indirectly from a primary insider from committing insider trading offences. ${ }^{29}$ Lastly, the Criminal Justice Act further discourages any secondary insider's tippees from indulging in insider trading. ${ }^{30}$

Furthermore, the Criminal Justice Act prohibits individuals from engaging in approximately three forms of conduct that would amount to insider trading. Firstly, individuals are prohibited from dealing in price-affected securities on the basis of non-public material inside information. ${ }^{31}$ Secondly, individuals are prohibited from encouraging (tipping) other persons to deal in price-affected securities on the basis of non-public material inside information. ${ }^{32}$ Lastly, the Criminal Justice Act prohibits individuals from knowingly and improperly disclosing non-public material inside information to other persons. ${ }^{33}$ No individual (insider) may be convicted of insider trading unless he knew that he was in possession of nonpublic inside information and dealt in the affected securities on the basis of such information.

Although the Criminal Justice Act introduced a number of significant changes such as a wider definition of securities, ${ }^{34}$ its provisions are still flawed in some respects. For instance, its prohibition may only give rise to criminal sanctions against individuals who practise insider trading. Put differently, the definition of "individual" only covers unincorporated partnerships or corporations comprising a collection of individuals. ${ }^{35}$ This is arguably one of the main weaknesses of the insider trading ban contained in the Criminal Justice Act. ${ }^{36}$ Moreover, individuals will only be liable for insider trading when they deal in affected securities on a regulated market or where such dealing is conducted on the over the counter markets through a professional intermediary. ${ }^{37}$

Apart from the Criminal Justice Act, the insider trading practice is also indirectly prohibited in the Companies Act $2006 .{ }^{38}$ For instance, the directors of a company are prohibited from accepting benefits from third parties ${ }^{39}$ and dealing in such company's securities if they have a direct or indirect interest that contradicts the interests of the company, especially with regard to their use of privileged inside information to avoid possible conflicts of interests and/or insider trading. ${ }^{40}$ Moreover, circumstances in which a company can deal in its own securities or capital to repurchase, cancel stock, or redeem preference shares are carefully regulated to prevent the abuse of non-public price-sensitive information through insider trading. ${ }^{41}$

\subsection{Evaluation and Analysis of the Historical Overview of Insider Trading Prohibition}

In contrast to the developments of the regulation and enforcement of the insider trading ban in the UK, ${ }^{42}$ the legislature in South Africa introduced a prohibition on insider trading in $1973 .{ }^{43}$ However, both South Africa and the UK's insider trading regulatory frameworks prohibit individuals from committing insider trading offences, especially in relation to securities listed on regulated financial markets. ${ }^{44}$ Moreover, both South Africa ${ }^{45}$ and the UK's ${ }^{46}$ insider trading regulatory frameworks prohibit primary insiders, secondary insiders and their tippees from knowingly dealing directly or indirectly ${ }^{47}$ in securities on the basis of non-public price-sensitive (material) inside information for their own benefit or for the benefit of

\footnotetext{
${ }^{28} S 57(1)(a) \&(2)(a)$

${ }^{29} S 57(1)(b) \&(2)(b)$

30 S 57. Also see generally Rider, Alexander, Linklater \& Bazley Market Abuse and Insider Dealing 47.

${ }^{31} \mathrm{~S} 52(1)$.

$32 S 52(2)(a)$.

${ }^{33} S 52(2)(b)$. It is of interest to note that individuals could be liable for insider trading in terms of $s 52$ if the prosecuting authorities prove that such accused individuals are insiders as stipulated in $s 57$ and that they were in possession of non-public inside information as proscribed in $s 56$ of the Criminal Justice Act. See Part V of the Criminal Justice Act. See further Rider, Alexander, Linklater \& Bazley Market Abuse and Insider Dealing 46-51.

34 This definition of securities included shares, debentures and derivatives in companies as well as gilts and local authority stock in both local and foreign public bodies and their derivatives. See Schedule 2 of the Criminal Justice Act.

${ }_{35}$ This could suggest that other corporations and entities like public companies are exempted from insider trading liability. Rider, Alexander, Linklater \& Bazley Market Abuse and Insider Dealing 46.

36 See further Rider, Alexander, Linklater \& Bazley Market Abuse and Insider Dealing 46.

${ }^{37}$ Face to face over the counter (OTC) transactions between non-professional intermediaries are excluded from insider trading liability under the Criminal Justice Act. Also see Avgouleas The Mechanics and Regulation of Market Abuse 320 \& Rider, Alexander, Linklater \& Bazley Market Abuse and Insider Dealing 46.

38 (c 46), hereinafter referred to as the Companies Act 2006.

$39 \mathrm{~S} 176$ of the Companies Act 2006.

${ }^{40}$ See s 175 of the Companies Act 2006 \& ss 177; 182; 187 read with s 178(2) of the same Act which imposes a duty on the directors to disclose their interests in proposed or ongoing transactions. See further Rider, Alexander, Linklater \& Bazley Market Abuse and Insider Dealing 20.

${ }^{41}$ Also see generally Part 18 of the Companies Act 2006 \& s 170(4) of the same Act which states that the general duties of directors shall be interpreted and applied in the same way as common law rules or equitable principles. This is probably aimed at affording equitable damages or redress to any persons prejudiced by insider trading. Rider, Alexander, Linklater \& Bazley Market Abuse and Insider Dealing 12-13 \&17-18.

42 See paragraph 2 above.

${ }^{43} S 233$ of the Companies Act 61 of 1973, hereinafter referred to as the Companies Act.

44 In other words, similar classes of individuals are discouraged from engaging in illicit insider trading activities in both South Africa and the UK.

${ }^{45}$ Ss 77; 78 \& 82 of the Financial Markets Act.

46 S 52 of the Criminal Justice Act.

47 Individuals (insiders) are therefore prohibited from encouraging or discouraging others to deal in the affected securities while in possession of non-public inside information or to improperly disclose non-public inside information relating to such securities.
} 
others. ${ }^{48}$

Unlike in the UK, ${ }^{49}$ there is no express provision that discourages dealing in securities on unregulated over the counter markets through agents or professional intermediaries in South Africa. ${ }^{50}$ This could be due to the fact that insider trading activities in the over the counter markets are probably very restricted since such transactions are mostly done on a face-to-face basis between persons who know each other quite well. Furthermore, although the words "through an agent" are used in some provisions that discourage insider trading under the Financial Markets Act, ${ }^{51}$ this Act does not expressly provide a statutory definition for the term "agent". 52

On the contrary, the term "professional intermediary" which is similar to the term "agent" is employed and fully defined in the UK. ${ }^{53}$ Notably, the South African insider trading ban has an unlimited extra-territorial application. Thus, in contrast to the UK's insider trading regime which only applies to any dealing that takes place on a regulated market which operates in the UK or if the person dealing in the price-affected securities is a professional intermediary or relies on a professional intermediary to deal in such securities on a regulated financial market in the UK, ${ }^{4}$ an insider who unlawfully deals in the South African securities listed on a foreign market can be prosecuted for insider trading in South Africa even if the territorial (nexus) link to South Africa does not exist. ${ }^{55}$ Furthermore, unlike the position in the Criminal Justice Act, ${ }^{56}$ insider trading is treated both as a civil and criminal offence in South Africa. ${ }^{57}$ Nevertheless, no attempt has been made to statutorily define the concept of insider trading in both South Africa ${ }^{58}$ and the UK. ${ }^{59}$

\section{Historical Overview of Market Manipulation Prohibition}

Notwithstanding the fact that market abuse also constitutes insider trading activity, ${ }^{60}$ this sub-heading will mainly discuss market manipulation and other forms of market abuse that do not necessarily amount to insider trading.

Market manipulation and other related market abuse activities have been statutorily prohibited in the UK, probably since the early 1860s. ${ }^{61}$ The initial attempt to prohibit market manipulation in the UK was made by the Larceny Act 1861. This Act criminalised fraudulent misrepresentations intended to create a false market. ${ }^{62}$ The second attempt to regulate market manipulation in the UK was possibly introduced under the Prevention of Fraud (Investments) Act 1939.63 However, this Act was repealed by the Prevention of Fraud (Investments) Act 1958. ${ }^{64}$ The Prevention of Fraud (Investments) Act 1958 prohibited dishonest concealment of material non-public inside information relating to any securities for personal gain or the benefit of others. ${ }^{65}$ However, its purported market abuse ban was extremely difficult to enforce, especially where the wrongful conduct was committed outside the UK.

As a result the legislature enacted a new market manipulation prohibition under the Financial Services Act. ${ }^{66} \mathrm{~A}$ two-fold market manipulation prohibition was formulated under the Financial Services Act. Firstly, it prohibited the making of misleading statements or concealment of material non-public inside information relating to any securities. ${ }^{67}$ Secondly, the Financial Services Act prohibited the perpetration of market manipulation through misleading conduct or practices. ${ }^{68}$

The market manipulation prohibition under the Financial Services Act was, however, flawed in some areas. For instance, it failed to obtain more convictions against the market manipulation offenders. This could have been triggered

\footnotetext{
${ }^{48}$ This could further indicate that similar conduct that may give rise to insider trading is prohibited in South Africa as well as in the UK.

49 Ss 59 \& 52(3) of the Criminal Justice Act.

50 Ss 78 \& 82 of the Financial Markets Act.

51 S 78(1)(a); (2)(a) \& (3)(a) read with $s 82$ of the Financial Markets Act.

${ }^{52}$ Although it can be argued that the ordinary meaning of the term "agent" is generally known to all the relevant persons, the Financial Markets Act did not provide an adequate and clear definition of this term for the purposes of improving the implementation of the insider trading prohibition in South Africa.

53 S 59 of Criminal Justice Act.

${ }^{54}$ Ss 62 \& 79(2) of the Criminal Justice Act which outlines the scope of the insider trading offence. See further Rider, Alexander, Linklater \& Bazley Market Abuse and Insider Dealing (2009) 56-57 \& Avgouleas The Mechanics and Regulation of Market Abuse 323-324.

55 Jooste 2006 SALJ 453; also see the definition of "regulated market" in s 77 of the Financial Markets Act.

56 See paragraph 2 above.

57 Ss 78 \& 82 of the Financial Markets Act.

58 Ss 77; 78 \& 82 of the Financial Markets Act.

59 See Part V of the Criminal Justice Act.

60 In light of this, it is essential to note that about seven types of market abuse practices are statutorily prohibited in the UK. Barnes Stock Market Efficiency, Insider Dealing 132; Russen Financial Services Authorisation, Supervision and Enforcement: A Litigator's Guide (2006) 206-208.

61 S 84 of the Larceny Act 1861 (24 and 25 Vict c 96). Also see Avgouleas The Mechanics and Regulation of Market Abuse 314.

62 S 84 of the Larceny Act 1861; also see R v Kylsant [1932] 1 KB 442, where the court employed s 84 of the Larceny Act 1861 and convicted Lord Kylsant for misrepresentations made in his company's prospectus \& see further related remarks in Avgouleas The Mechanics and Regulation of Market Abuse 314.

63 (c 16); see s 12(1).

64 (c 45); also see Avgouleas The Mechanics and Regulation of Market Abuse 314; Rider, Alexander, Linklater \& Bazley Market Abuse and Insider Dealing 44.

65 This was mainly aimed at discouraging market manipulation and other related market abuse practices. See further $s 13$ of the Prevention of Fraud (Investments) Act 1958.

${ }_{6}^{66}$ Also see generally Avgouleas The Mechanics and Regulation of Market Abuse 314; Rider, Alexander, Linklater \& Bazley Market Abuse and Insider Dealing 44.

67 S 47(1).

68 S 47(2). Also see Avgouleas The Mechanics and Regulation of Market Abuse 314; Black \& Nobles "Personal Pensions Misselling: The Causes and Lessons of Regulatory Failure" 1998 MLR 789; Rider "Policing the City-Combating Fraud and Other Abuses in the Corporate Securities Industry" 1988 Current Legal Problems 47 \& Swan Market Abuse Regulation (2006) 5.
} 
by its heavy reliance on the criminal sanctions alone to combat market manipulation or similar market abuse activities. ${ }^{69}$

In order to improve and align the UK's market abuse legislation with the international best standards, the legislature enacted the Financial Services and Markets Act. ${ }^{70}$ The Financial Services and Markets Act came into effect on 1 December 2001. This Act defined and treated market manipulation and other market abuse practices both as criminal and civil offences. The initial civil provisions of the Financial Services and Markets Act discouraged three conducts, namely the misuse of information, the making or publishing of false or misleading impressions and market distortion or manipulation. ${ }^{71}$ These provisions were extensively revised on 1 July 2005 after the adoption of the Treasury's Market Abuse $^{72}$ and Investment Recommendation (Media) Regulations ${ }^{73}$ to implement the EU Market Abuse Directive ${ }^{74}$ and its so-called Level 2 Implementing Measures. ${ }^{75}$

The new civil provisions under the Financial Services and Markets Act provided a broader and comprehensive definition of various conducts that could amount to market manipulation and other related market abuse practices. ${ }^{76}$ These provisions also retained civil offences for engaging in conduct that will give rise to the misuse of material inside information ${ }^{77}$ and creation of a false or misleading impression or distortion of the financial markets. ${ }^{78}$ The new civil offence under the Financial Services and Markets Act is now applicable to both natural and juristic persons. ${ }^{79}$ Moreover, this civil offence need only be proved on the balance of probabilities. It is not necessary to prove intention on the part of the alleged offenders; negligent action or inaction may be sufficient for such offenders to incur liability. 80

In addition, as earlier indicated, there are seven types of market abuse practices in the UK and these practices will each now be briefly discussed. Firstly, insider dealing ${ }^{81}$ is expressly outlawed in the Financial Services and Markets Act. Consequently, any person or insider who deals or attempts to deal in qualifying and related investments on the basis of non-public price-sensitive inside information relating to the investments in question will incur civil liability under the Financial Services and Markets Act.82 Secondly, improper disclosure is also prohibited in the Financial Services and Markets Act. Accordingly, the disclosure of non-public price-sensitive information by an insider or any individual to another person in instances other than for the proper performance of his employment, profession or duties will give rise to a civil offence on the part of that individual under the Financial Services and Markets Act. ${ }^{83}$ Thirdly, any misuse of information is discouraged under the Financial Services and Markets Act. Therefore, conduct based on information that is not generally available but that would affect the decision of the investors to deal or not to deal in certain qualifying investments could amount to market manipulation or other market abuse offences. ${ }^{84}$ Such conduct must also be based on information which a "regular user" 85 of the market or the person in the position of the alleged offender would consider relevant in determining the terms on which to deal before civil liability can be imputed against any accused persons. ${ }^{86}$

Fourthly, manipulating transactions are further prohibited in the Financial Services and Markets Act. As a result,

\footnotetext{
${ }^{69}$ Avgouleas The Mechanics and Regulation of Market Abuse 308.

70 Avgouleas The Mechanics and Regulation of Market Abuse 307

71 See the original s 118(2)(a) to (c). Also see Russen Financial Services Authorisation, Supervision 185.

72 See the Financial Services and Markets Act 2000 (Market Abuse) Regulations 2005 SI 2005/381. Also see the Financial Services Authority's Market Abuse Directive Instrument 2005, 17 March 2005 \& the Financial Services Authority's Market Abuse Directive Disclosure Rules Instrument 2005, 17 March 2005.

732005 SI 2005/382

74 See Avgouleas The Mechanics and Regulation of Market Abuse 307 \& Russen Financial Services Authorisation, Supervision 206.

75 Also see Commission Directive 2003/124/EC of 22 December 2003 implementing Directive 2003/6/EC of 28 January 2003 on the definition and public disclosure of inside information and the definition of market manipulation [2003] OJ L339/70; Commission Directive 2003/125/EC of 22 December 2003 on the fair presentation of investment recommendations and the disclosure of conflicts of interest [2003] OJ L339/073. Also see Avgouleas The Mechanics and Regulation of Market Abuse 259-260 \& 307 for further related analysis.

76 S 118(1) to (8); also see the initial Part VIII of the Financial Services and Markets Act.

77 S 118(2) to (4) of the Financial Services and Markets Act.

78 See s 118(5) to (8) of the Financial Services and Markets Act. These civil offences are enforced parallel to the criminal offences contained in the Criminal Justice Act.

79 See s 150 read with ss 90; 380; 382; 118(1); 118B \& 118C of the Financial Services and Markets Act. Additionally see Avgouleas The Mechanics and Regulation of Market Abuse 391-446 for related analysis.

80 It is only primarily important to establish whether the alleged market abuse conduct occurred in relation to any qualifying investments on a prescribed market before imposing any liability on the alleged offenders. Prescribed markets include but are not limited to markets listed under the rules of the United Kingdom recognised investment exchange such as the London Stock Exchange, the International Petroleum Exchange, the London Metal Exchange, EDX London, Euronext-LIFFE and Virt-x. Qualifying investments include financial instruments like options, bonds and other forms of securities debt, derivatives on commodities, company shares (and securities equivalent to company shares), money market instruments, financial futures contracts, forward interest rate agreements, interest rate, equity swaps and other securities giving right to acquire shares or bonds. See $s$ 118(1)(a) \& (b) of the Financial Services and Markets Act; also see Russen Financial Services Authorisation, Supervision 206-208; Barnes Stock Market Efficiency, Insider Dealing 129-132 \& Rider, Alexander, Linklater \& Bazley Market Abuse and Insider Dealing 74-75.

81 This conduct is also criminally prohibited under the Criminal Justice Act. See paragraph 2 above.

82 S 118(2). Also see further Barnes Stock Market Efficiency, Insider Dealing 132-133 \& Rider, Alexander, Linklater \& Bazley Market Abuse and Insider Dealing $72-73$ \& 78

$83 \mathrm{~S} \mathrm{118(3).} \mathrm{In} \mathrm{other} \mathrm{words,} \mathrm{the} \mathrm{disclosure} \mathrm{of} \mathrm{inside} \mathrm{information} \mathrm{by} \mathrm{a} \mathrm{director} \mathrm{of} \mathrm{a} \mathrm{company} \mathrm{to} \mathrm{another} \mathrm{person} \mathrm{in} \mathrm{mere} \mathrm{social} \mathrm{context} \mathrm{or} \mathrm{selective} \mathrm{briefing} \mathrm{of} \mathrm{market} \mathrm{participants} \mathrm{like}$ financial analysts by directors or other persons with managerial positions will suffice for such persons to incur liability for improper disclosure of inside information.

$84 \mathrm{~S}$ 118(4).

85 S 130 A read with ss 118 A \& $118 \mathrm{C}$ of the Financial Services and Markets Act.

${ }_{86}$ Factors that are considered when determining whether the information in question is relevant to a "regular user" includes the extent to which the information is reliable (including how close the person or offender involved is to the tipper or the person who is the original source); whether such information is not already generally available to market participants and whether the information is fresh and different from information which is generally available or that would lead to a disclosure to be made in the future. Also see Barnes Stock Market Efficiency, Insider Dealing 134 \& Rider, Alexander, Linklater \& Bazley Market Abuse and Insider Dealing 78-80 \& Avgouleas The Mechanics and Regulation of Market Abuse
} 344-345. 
any behaviour or dealing that gives a false or misleading impression of the supply of or demand for one or more investments to raise the price of the investments in question to abnormal or artificial levels amounts to a civil offence of market manipulation. ${ }^{87}$ Such behaviour also includes the making of false or misleading transactions so as to give a false impression of the volume of trade in the affected securities. ${ }^{88}$ Manipulating transactions further includes price positioning. This usually occurs when a person enters small orders into an electronic trading system at prices which are higher than the previous bid or lower than the previous offer, in order to move the price of the qualifying investments in question. ${ }^{89}$ Fifthly, manipulating devices are also prohibited under the Financial Services and Markets Act. Accordingly, any persons who trade or place orders to trade through employing fictitious devices or any other form of deception or contrivance will incur civil liability for market manipulation. ${ }^{90}$ Examples of conduct that involve the use of manipulative devices include "flipping" or disclosing conflicting statements about certain qualifying investments through the Internet and engaging in transactions that are aimed at concealing the ownership of a qualifying investment to avoid compliance with the disclosure requirements.

Sixthly, illicit dissemination of information is prohibited in the Financial Services and Markets Act. Put differently, an insider or any person who knowingly gives information that conveys or is likely to convey a false or misleading impression about an investment or the issuer of an investment will be liable for market manipulation. ${ }^{91}$ Lastly, distortion and misleading behaviour is also outlawed in the Financial Services and Markets Act. In other words, any conduct that gives a false or misleading impression of either the demand for or the supply of investments and behaviour that distorts or is likely to distort the market in such investments leads to civil liability on the part of the offenders. ${ }^{92}$

A separate civil prohibition against persons who encourage or require others to engage in market manipulation or other market abuse activities is also proscribed in the Financial Services and Markets Act. ${ }^{93}$ The requirement or encouragement offence is committed where, by taking or refraining from taking any action, ${ }^{94}$ a person in question has required or encouraged others to indulge in market manipulation or other related market abuse activities. This may indicate that the Financial Services and Markets Act has a broader market abuse civil prohibition than its predecessors.

Market manipulation is also treated as a criminal offence under the Financial Services and Markets Act. ${ }^{95}$ Precisely, any person who makes misleading statements or who dishonestly conceals material facts relating to qualifying investments for the purpose of inducing or who is reckless as to whether they may induce other persons to enter or exercise or refrain from exercising any rights conferred by the relevant investments will be criminally liable for market manipulation. ${ }^{96}$

Furthermore, engaging in misleading practices and conduct which creates a false or misleading impression in respect of the market or the value of any qualifying investments for the purposes of creating that impression and inducing other persons to acquire, dispose of, subscribe for, or underwrite such investments or to refrain from doing so is criminalised under the Financial Services and Markets Act. ${ }^{97}$ This presupposes that misleading statements or omissions and other forms of market manipulation such as artificial transactions and trade-based manipulations are further prohibited and criminalised under the Financial Services and Markets Act. 98

Market manipulation has further been indirectly made a criminal offence under the Fraud Act. ${ }^{99}$ This Act introduced a new general offence fraud which discourages false representations, failure to disclose non-public material inside information and fraud by abuse of position. ${ }^{100}$ Thus, although it is most likely that violations for market manipulation or other related activities may be prosecuted under the Financial Services and Markets Act or the Criminal Justice Act, such violations may also fall under the general offence of fraud as stipulated in the Fraud Act. ${ }^{101}$

\footnotetext{
87 S 118(5).

${ }^{88}$ For example, wash trades; buying qualifying investments at the close of the market to mislead investors who act at closing prices; buying and selling a specific security by persons among themselves to create an illusion (painting the tape) of high volumes of trading.

89 Other examples of price positioning involve the so-called abusive squeezes, where a person has a position (directly or indirectly) in an investment under which quantities of qualifying investment or related investment are deliverable.

${ }^{90} \mathrm{~S}$ 118(6).

${ }^{91}$ S 118(7); also see further Barnes Stock Market Efficiency, Insider Dealing 138 \& Rider, Alexander, Linklater \& Bazley Market Abuse and Insider Dealing 78.

${ }_{22}$ S 118(8); also see Russen Financial Services Authorisation, Supervision 206-207 \& Avgouleas The Mechanics and Regulation of Market Abuse 332-358 for further related analysis.

${ }^{9}$ S 123; also see Rider, Alexander, Linklater \& Bazley Market Abuse and Insider Dealing 78.

${ }^{94}$ Rider, Alexander, Linklater \& Bazley Market Abuse and Insider Dealing 78; the Financial Services Authority (hereinafter referred to as the FSA), see the FSA's Code of Market Conduct 1.8.2.

${ }^{95} \mathrm{~S} 397$. This section replicates s $47(1)$ of the Financial Services Act.

${ }^{96} S$ 397(1) \& (2). Also see Avgouleas The Mechanics and Regulation of Market Abuse 314-316.

${ }_{97}^{97}$ See $s$ 397(3). While the prohibition under s 397(1) \& (2) requires proof of dishonest or recklessness, liability in terms of s 397(3) may suffice even where mere misleading acts were executed by the accused persons. Also see Avgouleas The Mechanics and Regulation of Market Abuse 314-318.

98 S 397(3). Also see Avgouleas The Mechanics and Regulation of Market Abuse 318-320.

992006 (c 35), hereinafter referred to as the Fraud Act.

${ }^{100} \mathrm{~A}$ person may be regarded as having abused their position to commit market abuse even when their conduct consisted of an omission rather than an actual act. See $s 4$ read with $s$ 3.

101 Barnes Stock Market Efficiency, Insider Dealing 128-129.
} 


\subsection{Evaluation and Analysis of the Historical Overview of Market Manipulation Prohibition}

Although market manipulation has been discouraged in the UK from as early as the $1860 \mathrm{~s},{ }^{102}$ it was only statutorily prohibited in South Africa in the late 1980s. ${ }^{103}$ Prior to this, market manipulation was mainly prohibited by the common law in South Africa. ${ }^{104}$ In contrast to the position in the UK where the concept of, and conduct amounting to market manipulation or other market abuse practices is statutorily defined, ${ }^{105}$ this concept is not statutorily defined in the Financial Markets Act.106

Moreover, unlike the position in the UK where about seven types of market abuse are clearly enumerated and statutorily prohibited, only three forms of market abuse practices, namely insider trading, prohibited trading practices (trade-based market manipulation) and the making or publication of false, misleading or deceptive promises, statements or forecasts (disclosure-based market manipulation) are statutorily discouraged in South Africa. ${ }^{107}$ Moreover, unlike the position under the Financial Markets Act, ${ }^{108}$ the Financial Services and Markets Act treats insider trading ${ }^{109}$ market manipulation and other forms of market abuse practices on a more equal footing in the UK. ${ }^{110}$ For instance, as discussed earlier, ${ }^{111}$ market manipulation and other market abuse practices are all treated as civil or criminal offences under the Financial Services and Markets Act in the UK. This approach is desirable in that it has enabled the FSA and other enforcement authorities to enforce the market abuse prohibition consistently in order to combat market manipulation and other related practices in the UK. In view of this and notwithstanding the fact that the market manipulation victims could utilise the relevant provisions of the Financial Institutions (Protection of Funds) Act ${ }^{112}$ to recover their damages, it is submitted that the Financial Markets Act should be amended to enact provisions that extends the civil liability compensation orders to cases involving market manipulation ${ }^{113}$ in order to improve and increase the enforcement of the market abuse ban in South Africa. ${ }^{114}$

Notably, behaviour would constitute market manipulation and/or other market abuse offences in terms of the Financial Services and Markets Act if it occurs in the UK or in relation to any qualifying investments which are mainly traded on a prescribed market in the UK ${ }^{115}$ or the relevant EU member states. Thus, in order for the FSA to impose liability on the alleged offenders, there must be a territorial nexus with the relevant financial markets in the UK or elsewhere. This could imply that the UK's provisions on market manipulation and other market abuse practices have a restricted extra-territorial application. ${ }^{116}$

However, in South Africa, conduct may amount to market manipulation or insider trading if it was made in relation to securities listed on a regulated market (whether domestic or foreign) which is run in terms of the laws of the country in which the market conducts business as a market for dealing in securities listed on that market. ${ }^{117}$ This implies, in contrast to the position in the UK, ${ }^{118}$ that the South African market abuse prohibition is unlimitedly applicable to securities listed on any regulated foreign market and to both natural and juristic persons. ${ }^{119}$ However, it remains to be seen whether the South African enforcement authorities will be able to mobilise and have sufficient resources necessary to implement and enforce the prohibition on market manipulation extra-territorially. Moreover, it is not expressly and statutorily provided how this so-called extra-territorial application will be utilised to protect the South African financial markets from non-resident persons who manipulate securities listed on a foreign market where such conduct has no effect on the related securities

\footnotetext{
102 See paragraph 3 above.

${ }^{103} \mathrm{Also}$ see the relevant provisions of the now repealed statutes, the Stock Exchanges Control Act 1 of 1985, hereinafter referred to as the Stock Exchanges Control Act, see s 40 \& the Financial Markets Control Act 55 of 1989, hereinafter referred to as the Financial Markets Control Act, see s 20 to s 23 . Notably, s 1 of the Stock Exchanges Control Act prohibited the market manipulation of securities which included stocks, shares and debentures while the relevant provisions of the Financial Markets Control Act prohibited market manipulation of financial instruments, as defined in s 1 including futures contracts, option contracts and loan stock on a financial market. Also see Cassim "An Analysis of Market Manipulation under the Securities Services Act 36 of 2004 (Part 1)" 2008 SA Merc LJ 3334.

104 Under common law, market manipulation is usually referred to as a crime of "rigging the market". Also see Cassim 2008 SA Merc LJ 34; 40-42.

$105 S 118$ of the Financial Services and Markets Act.

${ }_{106}$ See ss 80 \& 81 read with s 77. Also see further Cassim 2008 SA Merc LJ 34-35.

107 Ss 78; 80; 81 \& 82 of the Financial Markets Act.

108 This Act does not impose civil liability on persons who make or publish false, misleading or deceptive statements, promises and forecasts (disclosure-based market manipulation)

or engage in prohibited trading practices (trade-based market manipulation). See ss 80 \& 81 read with ss 78 \& 82 of the Financial Markets Act.

109 See further paragraph 2 above.

110 S 118.

111 See paragraph 3 above.

11228 of 2001, hereinafter referred to as the Protection of Funds Act.

113 See ss 80 \& 81 of the Financial Markets Act.

114 This approach could, if properly enforced, increase market abuse deterrence in South Africa without causing double jeopardy and/or over-criminalisation.

115 S $118 A(1)(a)$.

116 See related remarks in paragraph 3 read with paragraphs $2 ; \& 2.1$ above.

$117 \mathrm{~S} 77$ of the Financial Markets Act, for the definition of "regulated market".

118 S 118 A(1)(a).

119 Ss 77; 78; 80; 81\& 82 of the Financial Markets Act. Also see generally Jooste 2006 SALJ 453; Cassim "Some Aspects of Insider Trading - Has the Securities Services Act, 36 of 2004 Gone too Far?" 2007 SA Merc LJ 44 66-67.
} 
listed on the regulated financial markets in South Africa. ${ }^{120}$

The legislature in the UK amended its market abuse legislation in order to align it with the EU Market Abuse Directive. ${ }^{121}$ In light of this, the FSA was conferred more powers as a single administrative regulator to ensure that the prohibition on market manipulation and related practices is consistently complied with. The FSA has, for instance, issued the Code of Market Conduct to guide all the relevant persons on conduct that amounts to market manipulation and related practices (including factors to be considered when determining whether such conduct amounts to market abuse) in the UK. ${ }^{122}$ This Code of Market Conduct has, for instance, stipulated some factors to be considered when determining whether a person dealing in any qualifying investment has created a false or deceptive appearance of a trading activity in relation to a certain security or an artificial price or value of the qualifying investment and the extent to which the price, rate or option volatility movements for the affected investment are outside their normal daily, weekly or monthly range. ${ }^{123}$ Although such market conduct is also prohibited by the Financial Markets Act, ${ }^{124}$ it is not quite clear whether the Financial Services Board (the FSB) has a similar Code or booklet containing the guidelines regarding the behaviour that amounts to market manipulation or related practices in South Africa.

In addition, market manipulation practices such as the creation of a false or deceptive appearance of trading activity in connection with a security, ${ }^{125}$ dealing that will create an artificial practice ${ }^{126}$ and placing orders to buy or sell listed securities in order to create an artificial price for a security or a false or deceptive appearance in trading activity in relation to that security ${ }^{127}$ are merely stated and prohibited in the Financial Markets Act. Similarly, like the UK, ${ }^{128}$ South Africa prohibits certain conduct that is deemed manipulative, improper, false or deceptive. ${ }^{129}$ For example, the Financial Markets Act discourages practices such as: (a) wash sales, ${ }^{130}$ (b) engaging in conduct that amounts to or creates matched orders, ${ }^{131}$ (c) buying orders at successively higher prices and selling such orders at successively lower prices in order to improperly influence the market prices of certain securities, ${ }^{132}(d)$ entering orders to buy securities (marking the close) at or near the close of the market to change or maintain the close price of a listed security, ${ }^{133}$ (e) auctioning process, ${ }^{134}$ (f) effecting a market corner, ${ }^{135}$ and (g) maintaining an artificial price. ${ }^{136}$ Notably, employing manipulating devices, schemes or artifices or manipulative act, practice or course of business to defraud other investors ${ }^{137}$ is no longer expressly outlawed under the Financial Markets Act. ${ }^{138}$ Furthermore, in contrast to the position in the UK, disclosurebased market manipulation and/or other related activities that are perpetrated through the Internet are not statutorily prohibited in the Financial Markets Act. ${ }^{139}$ Moreover, the Financial Markets Act does not expressly provide practical guiding factors on how to determine whether certain practices may be deemed to be amounting to market manipulation. ${ }^{140}$

\section{Available Penalties}

Civil, criminal and administrative penalties are employed in the UK to combat and discourage market abuse practices. However, it is important to note that the discussion under this sub-heading will mainly focus on penalties as proscribed in the Criminal Justice Act and the Financial Services and Markets Act.

Criminal penalties may be imposed on all persons who knowingly engage in market abuse practices in the UK. Thus, the contravention of the insider trading provisions contained in the Criminal Justice Act ${ }^{141}$ and other market abuse

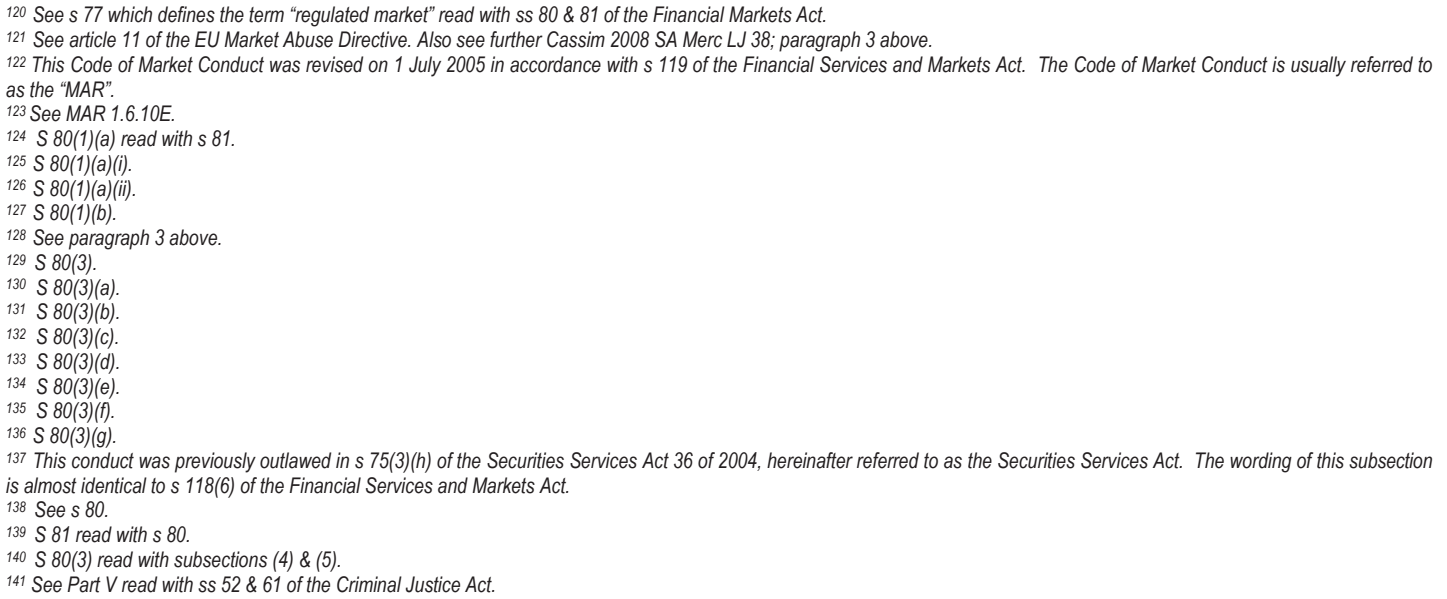


provisions contained in the Financial Services and Markets Act will give rise to criminal penalties in the UK. ${ }^{142}$ Criminal penalties for insider trading under the Criminal Justice Act may only be imposed on individuals. ${ }^{143}$ However, the criminal penalties for insider trading under the Financial Services and Markets Act are now applicable to both natural and juristic persons. ${ }^{144}$ Criminal penalties that may be imposed on individuals for insider trading or market manipulation include a fine or imprisonment for a term not exceeding six months, or both on summary conviction; or upon conviction on indictment, a fine or imprisonment for a term not exceeding seven years, or both. 145

The perpetrators of market abuse in the UK may also be liable for civil penalties. Although these penalties apply to both juristic and natural persons under the Financial Services and Markets Act, ${ }^{146}$ there are no civil penalties for insider trading under the Criminal Justice Act. ${ }^{147}$ Civil penalties that may be imposed on the perpetrators (offenders) of market abuse under the Financial Services and Markets Act comprise unlimited monetary fines, ${ }^{148}$ disgorgement of profits and/or the payment of compensation to the prejudiced persons. ${ }^{149} \mathrm{~A}$ number of factors have to be considered when determining the appropriate amount of the fine to be imposed on the offenders. Such factors are provided for in the Financial Services and Markets Act as well as in the enforcement section of the FSA's Enforcement (Manual) Handbook. ${ }^{150}$ The factors include the following: (a) the adverse effect of the behaviour on the market in question; (b) whether the person on whom the penalty is to be imposed is an individual or a juristic person; (c) the amount of profits accrued or loss avoided; (d) the degree to which the conduct in question was deliberate or reckless and (e) the conduct following the behaviour of the alleged offender in question. ${ }^{151}$

With regard to the last factor, the FSA may further consider the degree of co-operation that the accused person gave during the investigations of the wrongful conduct and whether any remedial steps were taken by that person from the time that behaviour was initially identified. ${ }^{152}$

The courts may, at the request of the FSA, further impose monetary fines on a person who violates any market abuse provisions. ${ }^{153}$ This usually follows after an application to the court by the FSA for an injunctive or restitution relief. ${ }^{154}$

In addition, a number of administrative penalties are used to curb market abuse in the UK. ${ }^{155}$ For example, disciplinary sanctions such as variation of (withdrawal of authorisation) Part IV permission; 156 injunctions (including cease or desist orders) to take remedial steps, secure or freeze assets and to discourage a certain conduct. ${ }^{157}$ These court injunctions can be imposed on any person who commits market abuse practices, regardless of whether such person is regulated by the FSA. ${ }^{158}$ Other administrative penalties that can be levied against market abuse offenders are public censure, ${ }^{159}$ withdrawal of approval on former approved persons who are not fit to perform their initial authorised functions, ${ }^{160}$ prohibition of individuals who engage in illicit trading activities from dealing or carrying out functions related to regulated activities ${ }^{161}$ and imposing restitution and redress orders on any persons who commit market manipulation and/or other market abuse offences. ${ }^{162}$ It should be borne in mind that these administrative penalties are applicable to all persons (natural and juristic persons) especially under the Financial Services and Markets Act. ${ }^{163}$

The Financial Services and Markets Act further confers a private right of action to the FSA to apply to the courts for a restraining order or restitution order against any person who knowingly contravenes its relevant market abuse

\footnotetext{
142 S 402 read with s 397 of the Financial Services and Markets Act; also see Part V of the Criminal Justice Act.

143 See paragraph 2 read with paragraphs $2.1 \& 3$ above.

${ }_{144} S$ 402; see related remarks in paragraph 3 above.

145 S 402 of the Financial Services and Markets Act; also see Avgouleas The Mechanics and Regulation of Market Abuse 323-324 \& Rider, Alexander, Linklater \& Bazley Market Abuse and Insider Dealing 93-94.

146 S 402; see similar comments in paragraph 3 above.

147 See Part V; also see related remarks in paragraph 2 above.

148 S 123(1).

${ }^{149}$ Also see further Avgouleas The Mechanics and Regulation of Market Abuse 375; Rider, Alexander, Linklater \& Bazley Market Abuse and Insider Dealing 94.

150 Release 064 April 2007, which is hereinafter referred to simply as the "ENF".

151 See further ss 205; 206 \& 210 of the Financial Services and Markets Act. See further ENF 14.7.4G \& Avgouleas The Mechanics and Regulation of Market Abuse 374-377.

152 See ENF 14.7.4.G(5). Also see Swan Market Abuse Regulation 113-123.

153 S 129 of the Financial Services and Markets Act.

154 S 384 read with ss 381 \& 383 of the Financial Services and Markets Act; also see Russen Financial Services Authorisation, Supervision 147-151.

155 Swan Market Abuse Regulation 112.

156 Ss 53 \& 54 read with s 63 of the Financial Services and Markets Act; also see ENF 3,4 \& 5

157 See ss 380 \& 381 of the Financial Services and Markets Act. Also see ENF 6.1.1.G; ENF 6.2.1.G; ENF 6.6.1.G; ENF 6.3.2.G \& ENF 6.3.7.G.

158 ENF 6.1.1.G. A person who disobeys or fails to comply with an injunction may be held in contempt of court and could be liable to imprisonment, monetary fine or seizure of the assets. S 206 of the Financial Services and Markets Act; also see ENF 6.2.5.G \& see further Swan Market Abuse Regulation 125.

159 S 205 of the Financial Services and Markets Act; also see ENF 12.

160 S 59 read with ss 66 \& 210 of the Financial Services and Markets Act. Also see ENF 7.5.1.G.

161 S 56(2) of the Financial Services and Markets Act. See generally ENF 8.1.2.G.

162 Ss 382; 383 \& 384 of the Financial Services and Markets Act. Also see ENF 9.1.2.G; ENF 9.4.2.G \& ENF 9.5.1.G. See further Russen Financial Services Authorisation, Supervision 136-166.

163 In this regard, it should be noted that administrative penalties under the Criminal Justice Act are possibly still limited to individuals (natural persons) alone.
} 
provisions. ${ }^{164}$ In addition, the FSA may also seek a court order against any alleged offenders to disgorge the profits gained or directly pay compensation to the persons affected by their market abuse activities. ${ }^{165}$ Although a civil private right of action is available as indicated above to the persons who suffer losses due to other forms of market abuse, there is no such express private right of action for persons affected by market manipulation as contained in the Financial Services and Markets Act ${ }^{166}$ and insider trading as contained in the Criminal Justice Act. ${ }^{167}$

\subsection{Evaluation and Analysis of the Available Penalties}

The UK, ${ }^{168}$ South Africa uses civil, criminal169 and administrative penalties and/or remedies to combat market abuse practices. As is the position in the UK ${ }^{170}$ and as indicated above, criminal and administrative penalties are used to discourage all forms of market abuse in South Africa. ${ }^{171}$ On the other hand, civil penalties are employed only to curb insider trading under the Financial Markets Act. ${ }^{172}$ In contrast to this position in South Africa, no civil penalties for insider trading are provided for under the Criminal Justice Act in the UK. ${ }^{173}$ However, a number of civil penalties are now available to discourage and curb insider trading as well as other market abuse practices under the Financial Services and Markets Act. ${ }^{174}$

With regard to criminal penalties, South Africa rigidly imposes a maximum fine of R50 million, or imprisonment for a period not exceeding ten years, or both such fine and imprisonment against the offenders. ${ }^{175}$ In contrast to this, unlimited monetary and other penalties may be imposed on the offenders by the FSA in the UK. ${ }^{176}$

As earlier discussed, ${ }^{177}$ several factors are considered in order to determine appropriate civil monetary fines that will be imposed on the market abuse offenders in the UK. Likewise, almost similar factors are used to determine appropriate civil compensatory fines and administrative penalties in South Africa. ${ }^{178}$ Moreover, like the UK, ${ }^{179}$ and as already indicated above, South Africa imposes a variety of unlimited administrative penalties on persons who commit market abuse offences. ${ }^{180}$ Additionally, like the FSA, ${ }^{181}$ the FSB is now allowed to publish by notice on its official website or by means of other appropriate public media, any outcome, status or details of market abuse investigations (public censure) if such publication is in the public interest. ${ }^{182}$

\section{Concluding Remarks}

As earlier stated, 183 it is submitted that the failure to provide separate and distinct penalties for companies and individuals could have marred the successful enforcement of the market abuse ban in South Africa to date. Accordingly, it is recommended that the FSB should be expressly and statutorily authorised to impose separate and different penalties on individuals and juristic persons or companies that engage in market abuse activities in South Africa. Put differently, the FSB should be expressly and statutorily authorised to impose separate, different and unlimited monetary and other appropriate penalties on individuals and juristic persons or companies that engage in market abuse activities in South Africa. Over and above, it is suggested that the FSB, like the FSA, ${ }^{184}$ should carefully and consistently utilise its statutory powers to publicise the names of the culprits who commit market abuse offences (public censure or name and shame approach) in South Africa. ${ }^{185}$

\footnotetext{
164 Ss 150; 380 \& 382. The court orders for a private right of action do not however, apply to market abuse violations regarding s 397 of the Financial Services and Markets Act. 165 See Rider, Alexander, Linklater \& Bazley Market Abuse and Insider Dealing 94.

${ }_{166}$ S 397 of the Financial Services and Markets Act; also see Rider, Alexander, Linklater \& Bazley Market Abuse and Insider Dealing 94.

167 Part V of the Criminal Justice Act.

168 See paragraph 4 above.

169 S 109(a) of the Financial Markets Act.

170 See paragraph 4 above.

171 Ss 78; 80; 81 \& 82 of the Financial Markets Act.

172 S 82.

173 See paragraph 4 above.

174 The Financial Services and Markets Act; also see paragraph 4 above.

175 S 109(a) of the Financial Markets Act.

176 S 123(1) of the Financial Services and Markets Act; also see Avgouleas The Mechanics and Regulation of Market Abuse 375.

177 See paragraph 4 above.

178 See $s 6 D$ read ss $6 A ; 6 B$ \& $6 C$ to 61 of the Protection of Funds Act. Read with ss 82 \& 99 of the Financial Markets Act \& see further Cassim "An Analysis of Market Manipulation under the Securities Services Act 36 of 2004 (Part 2)" 2008 SA Merc LJ 177195

179 See paragraph 4 above.

180 See ss 6 A to 61 of the Protection of Funds Act; read with ss 82 \& 99 of the Financial Markets Act \& also see Cassim 2008 SA Merc LJ 195.

181 Ss 123(3) \& 124 of the Financial Services and Markets Act. Also see ENF 14.4.1.G.

182 S 84(2)(e) of the Financial Markets Act.

183 See related remarks in paragraph 4.1 read with paragraph 4 above.

184 Generally see paragraphs 2; 3 \& 4 above.

185 See related remarks in paragraph 4.1 above.
} 
Moreover, it is submitted, as is the position in the UK, 186 that the Financial Markets Act should be reviewed to enact provisions that give private rights of action to the affected persons for them to claim their damages directly from the market abuse offenders. In relation to this, it is submitted that the FSB should be statutorily required to provide its own Code of Market Abuse Conduct containing sufficient and adequate guidelines on factors that should be considered from time to time, in determining whether a trading practice and/or behaviour will give rise to or amounts to market abuse practices in order to increase the combating of such practices in South Africa.

It is further suggested that the Financial Markets Act should be amended to enact provisions that expressly and adequately define the concepts of "insider trading" and "market manipulation" in South Africa. Additionally, as is the position in the UK, 187 the Financial Markets Act should be amended to enact provisions that expressly discourage any market abuse activity or illicit dealing in securities on unregulated over the counter markets through agents or professional intermediaries and face-to-face transactions between non-professional intermediaries in South Africa. Lastly, the Financial Markets Act should also be reviewed to enact provisions that clearly enumerate sufficient guidelines or conditions under which the extra-territorial application of the market abuse ban will be employed to prevent cross-border market abuse activities consistently in South Africa and elsewhere.

\section{References}

Avgouleas E The Mechanics and Regulation of Market Abuse: A legal and Economic Analysis (Oxford University Press Oxford 2005) Barnes P Stock Market Efficiency, Insider Dealing and Market Abuse (Gower Publishing Limited Surrey England 2009) Beuthin RC and Luiz SM Beuthin's Basic Company Law $3^{\text {rd }}$ ed (Butterworths Durban 2000) Blair MQC \& Walker GA (eds) Financial Services Law 1st ed (Oxford University Press Oxford United Kingdom 2006) Lyon GJ \& Du Plessis JJ The Law of Insider Trading in Australia (The Federation Press Sydney 2005)

Rider B, Alexander K, Linklater L \& Bazley S Market Abuse and Insider Dealing $2^{\text {nd }}$ ed (Tottel Publishing Haywards Heath 2009) Russen J Financial Services Authorisation, Supervision, and Enforcement: A Litigator's Guide (Oxford University Press New York 2006) Swan EJ Market Abuse Regulation $1^{\text {st }}$ ed (Oxford University Press United States of America 2006)

\section{Journal articles}

Bhattacharya U \& Daouk H "The World Price of Insider Trading" 2002 Journal of Finance 75-108 Black J \& Nobles R "Personal Pensions Misselling: The Causes and Lessons of Regulatory Failure" 1998 MLR 789-820

Botha D "Control of Insider Trading in South Africa: A Comparative Analysis" 1991 SA Merc LJ 1-18

Botha D "Increased Maximum Fine for Insider Trading: A Realistic and Effective Deterrent?" 1990 SALJ 504-508

Cassim R "An Analysis of Market Manipulation under the Securities Services Act 36 of 2004 (Part 1)" 2008 SA Merc LJ 33-60

Cassim R "An Analysis of Market Manipulation under the Securities Services Act 36 of 2004 (Part 2)" 2008 SA Merc LJ 177-199

Cassim R "Some Aspects of Insider Trading - Has the Securities Services Act, 36 of 2004 Gone too Far?" 2007 SA Merc LJ 44-70

Jooste R "A critique of the insider trading provisions of the 2004 Securities Services Act" 2006 SALJ 437-460

Luiz SM "Insider Trading Regulation - If at First You Don't Succeed..." 1999 SA Merc LJ 136-151

Osode PC "The new South African Insider Trading Act: Sound law reform or legislative overkill?" 2000 Journal of African Law 239-263

Rider BAK "Policing the City-Combating Fraud and Other Abuses in the Corporate Securities Industry" 1988 Current Legal Problems 4768

Steinberg MI "Insider Trading Regulation-A Comparative Perspective" 2003 The International Lawyer 153-171

Van Deventer G "New watchdog for insider trading" 1999 FSB Bulletin 2-3

Van Deventer G "Harnassing Administrative Law in Encouraging Compliance" 2009 FSB Bulletin 3-4

\section{Case law}

South Africa

Pretorius and Another v Natal South Sea Investment Trust 19653 SA 410 (W)

United Kingdom

$R$ v Kylsant [1932] 1 KB 442

\footnotetext{
186 Generally see paragraph 4 above.

187 See paragraph 2 above, for related remarks.
} 


\section{Legislation}

South Africa

Companies Act 61 of 1973

Companies Act 71 of 2008

Consumer Protection Act 68 of 2008

Financial Institutions (Protection of Funds) Act 28 of 2001

Financial Markets Act 19 of 2012

Financial Markets Control Act 55 of 1989

Securities Services Act 36 of 2004

Stock Exchanges Control Act 1 of 1985

United Kingdom

Companies Act 1980 (c 22)

Companies Act 1985 (c 6)

Companies Act 2006 (c 46)

Company Securities (Insider Dealing) Act 1985 (c 8)

Criminal Justice Act 1993 (c 36)

Financial Services and Markets Act 2000 (c 8)

Financial Services Act 1986 (c 60)

Fraud Act 2006 (c 35)

Larceny Act 1861 (24 and 25 Vict c 96)

Prevention of Fraud (Investments) Act 1939 (c 16)

Prevention of Fraud (Investments) Act 1958 (c 45)

\section{European Union}

Commission Directive 2003/124/EC of 22 December 2003 implementing Directive 2003/6/EC of 28 January 2003 on the definition and public disclosure of inside information and the definition of market manipulation [2003] OJ L339/70

Commission Directive 2003/125/EC of 22 December 2003 on the fair presentation of investment recommendations and the disclosure of conflicts of interest [2003] OJ L339/073

European Union Directive on Insider Dealing and Market Manipulation, the Directive of the European Parliament and Council of 28 January 2003 on insider dealing and market manipulation (market abuse) 2003/6/EC [2003] OJ L96/16

European Union Insider Dealing Directive, Council Directive 89/592/EEC of 13 November 1989 [1989] OJ 1989 L334/30

\section{Commissions, committees, statutory instruments and reports}

\section{South Africa}

Financial Services Board Annual Report 2011

Financial Services Board Annual Report 2013

The King Task Group into Insider Trading Legislation Minority Report on Insider Trading 1997

The King Task Group into the Insider Trading Legislation First Report 15 May 1997

The King Task Group into the Insider Trading Legislation Final Report 21 October 1997

Van Wyk de Vries Commission of Inquiry into the Companies Act of 1973

\section{United Kingdom}

Financial Services and Markets Act 2000 (Market Abuse) Regulations 2005 SI 2005/381

Financial Services and Markets Act 2000 (Prescribed Markets and Qualifying Investments) Order 2001, SI 2001/1996 as amended by

Regulation 10 of the Market Abuse Regulations 2005

Financial Services Authority Handbook (Code of Market Conduct) FSA Release 19 July 2001

Financial Services Authority's Market Abuse Directive Disclosure Rules Instrument 2005, 17 March 2005

Financial Services Authority's Market Abuse Directive Instrument 2005, 17 March 2005

Insider Dealing (Securities and Regulated Markets) Order 1994

Traded Securities (Disclosure) Regulation 1994 


\section{Thesis and Dissertations}

Chitimira H A Comparative Analysis of the Enforcement of Market Abuse Provisions (LLD-thesis Nelson Mandela Metropolitan University 2012)

Chitimira H The Regulation of Insider Trading in South Africa: A Roadmap for an Effective, Competitive and Adequate Regulatory Statutory Framework (LLM-dissertation University of Fort Hare 2008)

\section{Newspaper Reports}

Chanetsa B "Insider Trading is Notoriously Hard to Prosecute" Business Report 26 April 2004

\section{Internet Sources}

Financial Services Board "Enforcement Committee Actions" Media Release (28-06-2011) <http://www.fsb.co.za/ftp://ftp.fsb.co.za /public/documents/AReport2011.pdf> (accessed 22-11-2013)

Financial Services Board "List of Current Investigations of the Directorate of Market Abuse" Media Release (28-06-2011) $<$ http://www.fsb.co.za/ftp://ftp.fsb.co.za/public/documents/AReport2011.pdf> (accessed 22-11-2013)

Myburgh A \& Davis B "The Impact of South Africa's Insider Trading Regime: A Report for the Financial Services Board" (25-03-2004) $<$ http://www.genesis-analytics.com/public/FSBReport.pdf> (accessed 09-02-2013)

Van Deventer G "Anti-Market Abuse Legislation in South Africa" (10-06-2008) <http://www.fsb.co.za/public/marketabuse/FSBReport.pdf> (accessed 05-05-2013) 